\title{
Efficacy of passive sand filtration in reducing exposure of salmonids to the actinospore of Myxobolus cerebralis
}

\author{
R. Barry Nehring ${ }^{1, *}$, Kevin G. Thompson ${ }^{1}$, Karen Taurman ${ }^{2}$, William Atkinson ${ }^{3}$ \\ ${ }^{1}$ Colorado Division of Wildlife, 2300 South Townsend Avenue, Montrose, Colorado 81401, USA \\ ${ }^{2}$ Colorado Division of Wildlife, 317 West Prospect Street, Fort Collins, Colorado 80526, USA \\ ${ }^{3}$ Colorado Division of Wildlife, 925 Weiss Drive, Steamboat Springs, Colorado 80477, USA
}

\begin{abstract}
The aquatic oligochaete Tubifex tubifex parasitized by Myxobolus cerebralis releases triactinomyxon (TAM) actinospores that can infect some species of salmonids and cause salmonid whirling disease. Silica sand was tested as a filtration medium for removal of TAMs from water containing the parasite. Laboratory tests indicated sand filtration removed $>99.99 \%$ of TAMs. In 2 different field tests, groups of 1 mo old rainbow trout Oncorhynchus mykiss were exposed for 2 wk to filtered and unfiltered water from a spring-fed pond enzootic for M. cerebralis. In November 2000, the exposure dose was estimated as between 3 and 5 TAMs fish $^{-1}$. During a March 2001 exposure, the estimated dose was between 286 and $404 \mathrm{TAMs} \mathrm{fish}^{-1}$. Fish were held for 6 mo post exposure (p.e.) in laboratory aquaria for observation and evidence of clinical signs of whirling disease. We used 4 diagnostic techniques to assess the prevalence and severity of infection by $M$. cerebralis among fish exposed to filtered and unfiltered water. These included polymerase chain reaction (PCR) for genomic DNA of the parasite, histological evaluation for tissue damage, tissue digestion for quantification of cranial myxospores of the parasite, and total non-sampling mortality that occurred over 6 mo p.e. All diagnostic tests verified that the prevalence and severity of infection was significantly reduced among fish in treatment groups exposed to filtered water compared to those exposed to unfiltered water in both the low-dose and high-dose exposures.
\end{abstract}

KEY WORDS: Salmonid whirling disease $\cdot$ Myxobolus cerebralis $\cdot$ Sand filtration

\section{INTRODUCTION}

Salmonid whirling disease (WD) is caused by the myxozoan parasite Myxobolus cerebralis. The parasite requires 2 hosts to complete its life cycle, a salmonid fish and the aquatic oligochaete Tubifex tubifex (Markiw \& Wolf 1983, Wolf \& Markiw 1984). The parasite produces myxospores in salmonid fishes that are either shed while the fish is alive (Nehring et. al. 2002) or released into the aquatic environment from carcasses of decaying fishes (El-Matbouli et al. 1992). Tubificid worms feeding head-down in organically rich bottom sediments can ingest these myxospores. Susceptible strains of T. tubifex that ingest the myxospores become infected, and subsequently release triactinomyxon
(TAM) actinospores of the parasite into the water. The released TAM is infective to many species of salmonid fishes, thus completing the parasite's life cycle.

The size and shape of the 2 spores are dramatically different. The myxospores are quite small, measuring approximately $8.7 \mu \mathrm{m}$ in length and $8.2 \mu \mathrm{m}$ in width. They are circular in appearance when viewed dorsally and somewhat ovoid in shape viewed laterally (ElMatbouli et al. 1992, El-Matbouli \& Hoffmann 1998). In contrast, the TAMs have the appearance of a grappling hook and are much larger in size. Each caudal process (arms of the grappling hook) measures $194 \pm 20 \mu \mathrm{m}$ in length (Lom et al. 1997, El-Matbouli \& Hoffmann 1998); therefore, the tip-to-tip distance across the caudal processes is approximately $400 \mu \mathrm{m}$. We hypo- 
thesized that the large size of the TAM might facilitate its removal from small amounts of flowing water using a silica-sand-based passive filtration system. Indeed, passive sand filtration for removal of various waterborne pathogens has been in use in England, Germany and the eastern United States since the 1800s (Hazen 1913, Bellamy et al. 1985). A passive flow-through mechanical filtration system could be useful for removal of TAMs from the small volumes of water needed to augment water supplies for aquaculture or from effluents of earth-bottom ponds contaminated with the parasite.

In 1995, Myxobolus cerebralis infections were detected in Age 1 (16 mo old) wild rainbow trout Oncorhynchus mykiss in the Fryingpan River drainage in central Colorado. By 1998, the abundance of Age 1 rainbow trout had declined $90 \%$ from the levels observed in 1994 (Nehring \& Thompson 2001). Water filtration studies as described by Thompson \& Nehring (2000) were conducted throughout the drainage from August 1998 through August 2002 to identify potential sources of TAMs responsible for the $M$. cerebralis infections in Age 1 wild rainbow trout in the river. The water filtration studies provided strong empirical evidence that the effluent emanating from a series of private fish ponds was the primary source of TAMs flowing into the Fryingpan River. The pond discharge flowed into the river $15 \mathrm{~km}$ upstream of the lower terminus of the $23 \mathrm{~km}$ study reach.

The objectives of our study were 2-fold. The first objective was to develop and test a silica-sand passive filtration system in the laboratory to determine the efficiency of trapping and removal of TAMs of the Myxobolus cerebralis parasite. Our second objective was to field test the efficiency of the system for attenuating or removing TAMs from a source of water enzootic for the parasite in a continuous flow-through situation. Flow-through testing was conducted on a portion of the effluent from the spring-fed ponds in the Fryingpan River drainage that were the source for large numbers of TAMs of the M. cerebralis parasite. We used 1 mo old rainbow trout not previously exposed to the parasite as test organisms for the flow-through testing experiments.

\section{MATERIALS AND METHODS}

Laboratory tests. The filter was constructed from a 3791 Rubbermaid ${ }^{\mathrm{TM}}$ stock water tank filled with a $10 \mathrm{~cm}$-thick layer of 2.5 to $6 \mathrm{~cm}$ diameter granite river rock. The layer of rock was overlaid with washed playground sand $>180 \mu \mathrm{m}$ diameter. The sand layer was $40 \mathrm{~cm}$ deep and separated from the rock layer by a $1 \mathrm{~mm}$ mesh window screen. Water piped onto the top of the filter passed through the sand and pooled in the layer of river rock, where it passed through a $50.8 \mathrm{~mm}$ diameter outlet valve. The approximate volume of the sand used in the filter was $325 \mathrm{l}$. For the laboratory tests, a reservoir containing $1900 \mathrm{l}$ of tap water was seeded with Myxobolus cerebralis TAMs and delivered to the top of the sand filter at an approximate flow rate of $271 \mathrm{~min}^{-1}$. The number of TAMs seeded in the 19001 reservoir ranged from 687000 to 1442000 for the 6 laboratory tests. Densities of TAMs for the tests averaged $443 \mathrm{l}^{-1}$, ranging from 361 to $759 \mathrm{l}^{-1}$. The $1900 \mathrm{l}$ of sand-filtered water was collected at the outlet of the Rubbermaid ${ }^{\mathrm{TM}}$ tank and filtered through a $20 \mu \mathrm{m}$ filter screen to collect any remaining TAMs. The concentrated filtrate was washed into a sample jar and examined by stereozoom microscopy for detection of TAMs using the protocol of Thompson \& Nehring (2000). The minimum detection limit by stereozoom microscopy was $<0.035 \mathrm{TAMs}^{-1}$ based on detection of $1 \mathrm{TAM}$ in $1.6 \mathrm{ml}$ of filtered water scanned by stereozoom microscopy and drawn from $105 \mathrm{ml}$ of filtrate originally concentrated from $1900 \mathrm{l}$. As a quality control check, $1.6 \mathrm{ml}$ of the filtrate was preserved in $70 \%$ analytical grade ethanol and tested by polymerase chain reaction (PCR) for the presence of DNA of the M. cerebralis parasite (Schisler et al. 2001). The test was a single-round modification of the test developed by Andree et al. (1998); 6 individual tests were completed during the laboratory-testing phase.

Field tests. Upon completion of the laboratory tests, 2 continuous-flow experimental exposures were conducted on the effluent emanating from the spring-fed ponds in the Fryingpan River drainage known to be enzootic for Myxobolus cerebralis. Each flow-through exposure lasted for $2 \mathrm{wk}$. The seasonal abundance of TAMs in the pond effluent was well documented from monthly filtrations conducted from July 1998 through September 2000. This information facilitated testing under 2 widely different levels of exposure. The first test, carried out between November 5 and 19, 2000, was a low-dose exposure. The second test was a highdose exposure conducted from March 5 to 19, 2001. At the end of each $2 \mathrm{wk}$ exposure, surviving rainbow trout fry were transported to an aquatic toxicology laboratory to be held for 6 mo post-exposure (p.e.).

For each exposure, specific-pathogen-free (SPF) 1 mo old rainbow trout (mean weight $0.4 \mathrm{~g}$ ) were held in filtered and unfiltered effluent water. In each experiment we exposed 1000 fish each to filtered and unfiltered water to insure that enough test fish survived in each of the 2 treatments to seed each of 4 replicate aquaria with a minimum of 100 rainbow trout fry for the 6 mo p.e. period. We used 2 exposure tanks similar to those in earlier studies (Thompson et al. 1999) for each experiment, one receiving 
filtered water, the other unfiltered water. Each tank was divided in half longitudinally and each half was stocked with 500 rainbow trout fry. The volume of each tank was approximately 1901 . A flow rate of approximately 4.8 to $6.7 \mathrm{l}^{-1}$ min was maintained for each tank throughout the experiments. Total tank volume was replaced 1.5 to 2.1 times $\mathrm{h}^{-1} ; 2$ Rubbermaid $^{\mathrm{TM}}$ stock tanks filled with silica sand were needed to provide the required flow to the tank receiving filtered effluent water in each experiment.

To monitor filtration efficiency and determine the level of exposure to TAMs for the fish exposed to unfiltered water, $24 \mathrm{~h}$ samples of filtered and unfiltered water were collected from each exposure tank upstream of the test fish using a small siphon that sub sampled the inflow to each tank. Siphons were calibrated to collect $1900 \mathrm{l}$ in $24 \mathrm{~h}$. This volume was passed through a $20 \mu \mathrm{m}$ filter screen installed below the siphon. The filtrate was collected and examined by stereozoom microscope to estimate the relative abundance of TAMs as previously described (Thompson \& Nehring 2000). Ambient water temperature during the field exposures ranged from 1.0 to $5.4^{\circ} \mathrm{C}$ in November 2000 and 2.3 to $7.3^{\circ} \mathrm{C}$ in March 2001.

At the end of the $2 \mathrm{wk}$ exposure, surviving test fish were transported to the Colorado Division of Wildlife Aquatic Toxicology wet laboratory at Fort Collins, Colorado. Groups exposed to filtered and unfiltered water treatments were randomly divided into 4 replicate aquaria for each treatment and held in SPF well water or dechlorinated tapwater until 1800 to 2400 degree-days $\left({ }^{\circ} \mathrm{C} \times \mathrm{d}\right)$ had elapsed to allow for adequate maturation of Myxobolus cerebralis myxospores. Daily fluctuations in water temperature were $<1^{\circ} \mathrm{C}$ during the p.e. period. Over the 10 mo holding period for the 2 experiments, water temperatures ranged from 7 to $15^{\circ} \mathrm{C}$ depending upon season. For the low-dose exposure, there were 103 fingerling rainbow trout per replicate at the start of the 6 mo p.e. holding period. The protocol called for a minimum of 20 fish in each aquaria to be tested for cranial myxospore concentrations at the end of the 6 mo p.e. period. Results of previous long-term exposure studies (Thompson et al. 1999) indicated it was likely that those fingerling rainbow trout exposed to unfiltered water during the high-dose experiment would suffer heavy mortality over the 6 mo p.e. holding period. To insure that adequate numbers of fish per replicate would survive to the end of the 6 mo holding period for pepsintrypsin digest (PTD) analysis in the high-dose experiment, each replicate aquarium was stocked with 218 trout. Each 901 aquarium was supplied with fresh water at a flow rate of $0.331 \mathrm{~min}^{-1}$.

We used 3 techniques to determine the prevalence and severity of infection by Myxobolus cerebralis among treatment groups: PCR testing to detect genomic DNA of the parasite (Andree et al. 1998, Schisler et al. 2001), histological sectioning for assessment of tissue damage (Baldwin et al. 2000), and PTD analysis for detection and quantification of cranial myxospores (Markiw \& Wolf 1974). At 30, 60, 90, 120 and 150 d p.e., at least 5 fish per replicate were sampled for PCR-testing. Fish were euthanized in an aqueous solution of methane tricaine sulfonate (MS222), frozen and shipped to a private laboratory for PCR analysis.

At 94 d p.e. in the low-dose experiment, 2 fish from each of 8 replicate aquaria were sacrificed for histological assessment of tissue damage. In the high-dose exposure, 10 fish exposed to filtered water and 20 fish exposed to unfiltered water and were sacrificed at $120 \mathrm{~d}$ p.e. for histological assessment of tissue damage. Trout euthanized for histological purposes were preserved in Bouin's solution for 24 to $72 \mathrm{~h}$, then transferred to $70 \%$ ethanol. Subsequently 3 or more tissue sections per head were processed by standard histological techniques, stained with hematoxylin and eosin and examined for evidence of Myxobolus cerebralis infection by light microscopy. Lesions were graded on a scale of 0 to 4, similar to that described by Baldwin et al. (2000), with 0 indicating no evidence of infection and 4 being most severe.

At the end of the 6 mo holding period, 20 or more fish per replicate were euthanized and analyzed by the PTD method for myxospores in cranial tissues (Markiw \& Wolf 1974). Fish heads were separated from the remainder of the body by cutting transversely on a vertical plane posterior to the operculum and the pectoral fin girdle; they were then frozen and shipped to the Colorado Division of Wildlife Aquatic Animal Health Laboratory for PTD processing.

Initially, all test fish were fed a commercial trout diet at a rate of $2.3 \%$ body weight $\mathrm{d}^{-1}$. The feeding rate was adjusted once each month as the fish grew, according to standard aquaculture guidelines (Piper et al. 1982). Once each week all aquaria were cleaned, and accumulated fecal material, detritus and other waste products were siphoned off the bottom. All aquaria were checked daily for moribund fish. Dead fish were removed from the aquaria and records of total mortality per replicate were kept during the p.e. period.

A 2 sample mean Student's $t$-test was used to test for differences in mortality among and between treatments (filtered versus unfiltered effluent) of rainbow trout in the low-dose and high-dose field experiments. Chisquared tests were used to check for differences in prevalence of infection in fish in the low-dose and high-dose exposures as determined with the PCR and PTD diagnostic tests. An alpha level of 0.05 was standard for all tests of significance. 


\section{RESULTS}

\section{Laboratory tests}

For the 6 laboratory tests, initial densities of TAMs in the unfiltered water ranged from 361 to $759 \mathrm{l}^{-1}$. Concentrated filtrate volumes collected from $1900 \mathrm{l}$ of water that passed through the sand filters ranged from $77 \mathrm{ml}$ to $105 \mathrm{ml}$ among the 6 tests. Sand filtration in all 6 tests reduced TAM levels below our minimum detection limits $\left(<0.035\right.$ spores $\left.\mathrm{l}^{-1}\right)$ with stereozoom microscopy. Moreover, Myxobolus cerebralis DNA in the filtered water was reduced below levels detectable by single-round PCR-testing (Schisler et al. 2001).

\section{Field tests}

No TAMs were detected in either experiment in effluent-water filtrates that had passed through the sand filters. In the November 2000 low-dose test, TAMs were detected in 2 of 7 unfiltered effluent filtrates. Actinospores were found in all unfiltered effluent filtrates $(n=12)$ during the March 2001 high-dose test. We estimated the range of exposure per fish in each experiment based upon the aforementioned flow rates through the holding tanks, tank volume, estimates of TAMs observed in the $24 \mathrm{~h}$ composite samples and an average filtration net efficiency of $50 \%$ (R. B. Nehring unpubl. data). Estimated cumulative exposure over the 2 wk exposure period, was 3 to 5 and 286 to 404 TAMs fish $^{-1}$ for the November 2000 and March 2001 experiments, respectively.

Results for the PCR, histology, and PTD tests are summarized in Table 1. Assessment of subsequent infection in fish using PCR indicated that sand filtration was effective in dramatically reducing the number of fish that became infected by Myxobolus cerebralis during the 2 wk exposure in both the low-dose and high-dose exposures. In the low-dose exposure, significantly fewer fish exposed to sandfiltered water tested PCR-positive $(0.8 \%)$ compared to the group exposed to unfiltered water (56.5\% tested positive) $\left(p=0.0000 ; \chi^{2}=98.3\right)$. Similarly, in the high-dose exposure, significantly fewer fish exposed to filtered water (14\%) tested PCR-positive, compared to $100 \%$ of the fish exposed to the unfiltered water $\left(p=0.0000 ; \chi^{2}=150.9\right)$.
In none of the fish exposed to filtered water and later analyzed by histopathology was there evidence of Myxobolus cerebralis infection at either the lowdose or high-dose exposures. Among fish exposed to unfiltered water in the low-dose test, histopathology indicated 5 of 8 had tissue damage characteristic of that caused by $M$. cerebralis (Baldwin et al. 2000). The severity of infection was low for all 5 fish with tissue damage, with each fish rated with a subjective score of Grade 1 on a scale from 0 (no infection) to 4 (severe infection). Among the 20 fish exposed to unfiltered water in the high-dose test, histopathology indicated that $100 \%$ had severe tissue damage (Grade 4) characteristic of that caused by $M$. cerebralis.

At the end of the 6 mo p.e. period, $\chi^{2}$ tests revealed highly significant differences in the prevalence of infection between groups of fish exposed to filtered and unfiltered water in both the low-dose and high-dose experiments. Among fish exposed to filtered water in the low-dose exposure, cranial myxospores were detected in only $1.3 \%$ of the fish tested, compared to $53.2 \%$ of the fish that tested positive after exposure to unfiltered water $\left(p=0.0000 ; \chi^{2}=122.5\right)$. Among fish exposed to filtered water in the high-dose exposure, cranial myxospores were detected in only $25.5 \%$ of the fish tested compared to $100 \%$ of the fish exposed to unfiltered water $\left(\mathrm{p}=0.0000 ; \chi^{2}=184.5\right)$.

Table 1. Oncorhychus mykiss. Results of polymerase chain reaction (PCR) histopathology, and pepsin-trypsin digest (PTD) tests on rainbow trout exposed to filtered and unfiltered effluent water from spring-fed ponds enzootic for Myxobolus cerebralis. Total sample size (n) and number of samples testing positive $(n+)$ are presented for each exposure, test and treatment. MG: mean grade of lesions on scale of 0 to 4 . Mean cranial myxospore levels for PTD test are for total sample (n)

\begin{tabular}{|c|c|c|c|c|c|c|c|c|}
\hline \multirow[b]{2}{*}{$\begin{array}{l}\text { PCR } \\
\text { Treatment }\end{array}$} & \multicolumn{4}{|c|}{ Nov 2000 (low-dose test) } & \multicolumn{4}{|c|}{ Mar 2001 (high-dose test) } \\
\hline & & $\mathrm{n}$ & $\mathrm{n}+$ & & & $\mathrm{n}$ & & $\mathrm{n}+$ \\
\hline Filtered & & 129 & 1 & & & 100 & & 14 \\
\hline Unfiltered & & 131 & 74 & 4 & & 100 & & 100 \\
\hline \multicolumn{9}{|c|}{ Histopathology } \\
\hline Treatment & & $\mathrm{n}$ & $\mathrm{n}+$ & MG & $\mathrm{n}$ & & $\mathrm{n}+$ & MG \\
\hline Filtered & & 8 & 0 & 0 & 10 & & 0 & 0 \\
\hline Unfiltered & & 8 & 5 & 1 & 20 & & 20 & 4 \\
\hline \multicolumn{9}{|c|}{ PTD cranial myxospores } \\
\hline Treatment & $\mathrm{n}$ & $\mathrm{n}+$ & Mean $^{a}$ & Range $^{b}$ & $\mathrm{n}$ & $\mathrm{n}+$ & Mean $^{\mathrm{a}}$ & Range $^{\mathrm{b}}$ \\
\hline Filtered & 159 & 2 & 3.84 & $6.97-604$ & 145 & 37 & 4.183 & $0.611-97.2$ \\
\hline Unfiltered & 293 & 156 & 49.4 & $0.76-1999$ & 160 & 160 & 1873 & $1.58-5173$ \\
\hline
\end{tabular}


Similarly, at the end of the 6 mo p.e. period, PTD testing revealed very large differences in the abundance of cranial myxospores between groups of fish exposed to filtered and unfiltered water in both the low-dose and high-dose experiments. Among fish exposed to filtered water in the low-dose experiment, mean concentrations of cranial myxospores were only $7.8 \%$ of the level observed in fish exposed to the unfiltered water. In the high-dose experiment, mean cranial myxospore levels among fish exposed to filtered water were only $0.2 \%$ of the levels observed in fish exposed to unfiltered water (Table 1).

Although PCR testing indicated that infection prevalence was much higher among test fish exposed to filtered effluent in the high-dose test compared to the low-dose test, i.e. 14 versus $0.8 \%$, mean cranial myxospore concentrations were similar when analyzed by PTD testing at the end of the p.e. period (Table 1).

There were large differences in the prevalence and severity of infection between groups of fish exposed to unfiltered water in the low-dose and high-dose experiments. In the low-dose test, $53.2 \%$ of fish exposed to unfiltered water had detectable numbers of myxospores compared to $100 \%$ among similarly exposed fish in the high-dose test. Among all fish exposed to unfiltered water and subjected to PTD testing, the mean number of cranial myxospores was 37.9 times higher in the group of fish from the high-dose exposure compared to those in the low-dose exposure (Table 1).

Total non-sampling mortality data for the 6 mo p.e. period for fish exposed to filtered and unfiltered water in the low-dose and high-dose experiments are summarized in Table 2. Mortalities among treatment fish exposed to unfiltered water in both the low-dose and high-dose exposures began $60 \mathrm{~d}$ p.e. Although the differences in mortality were not great among treatment groups in the low-dose exposure, fish exposed to the unfiltered water suffered significantly higher mortality ( $\mathrm{p}=0.034 ; t=2.74$ ) than those exposed to filtered water. In the high-dose experiment mortality among fish exposed to unfiltered water averaged $66.2 \%$ compared to $3.8 \%$ among the groups exposed to filtered water $(\mathrm{p}<$ $0.0001 ; t=48.7$ ). Differences in mean percent mortality among fish exposed to unfiltered water in the low-dose and high-dose tests were highly significant $(\mathrm{p}<0.0001 ; t=26.59)$. In contrast, there were no significant differences in percent mortality among fish exposed to filtered water in the low-dose versus the high-dose test ( $\mathrm{p}=0.838 ; t=-0.21)$.

\section{DISCUSSION}

Passive sand filtration for the removal of pathogens from surface water has been practiced around the world for almost 2 centuries. It has been in use in England, Germany and the eastern United States since the 1800s (Hazen 1913, Bellamy et al. 1985). Sand and other substances such as diatomaceous earth are effective media for filtering water to remove bacteria and other pathogens affecting human health, including species of Giardia and Cryptosporidium (Cleasby et al. 1984, Lange et al. 1986, Musial et al. 1987, Oram 1987, Schuler \& Ghosh 1990, Schuler et al. 1991).

Our laboratory tests indicated that passive sand filtration was highly efficient in removing Myxobolus cerebralis TAMs from water. However, sand filtration of pond effluent for removal of TAMs during the field exposures was not $100 \%$ efficient. Schuler et al. (1991) and Arndt \& Wagner (in press) also found that sand filtration was less than $100 \%$ efficient for the removal of various pathogens and particulates. This was particularly problematic among fish exposed to filtered water in the highdose experiment, where 14 and $25.5 \%$ of the fish tested by PCR and PTD were shown to be infected, respectively. Such levels of infection would be of great concern to the salmonid aquaculture industry.

We believe that the integrity of the sand filters was compromised during the high-dose exposure test in March 2001. At this time the ice cover from winter was beginning to melt in the spring-fed ponds. The ponds were located on a flat terrace of land adjacent to a sloping pasture that drained into the ponds. Several hundred beef cattle were being held in the pasture. Fecal material and detritus from the pasture was washed into the ponds by melting snow, causing the top 2 to $3 \mathrm{~cm}$ of sand in the filters to become plugged. This unanticipated problem necessitated the removal and replacement of the top 2 to $3 \mathrm{~cm}$ of sand once every other day during the 2 wk exposure

Table 2. Oncorhynchus mykiss. Total non-sampling mortality and percent mortality among 4 replicates per treatment of rainbow trout fingerlings held for 6 mo post-exposure after 2 wk of continuous exposure to sand-filtered and nonfiltered effluent water from spring-fed ponds enzootic for Myxobolus cerebralis. Each of the 8 replicate aquaria contained 103 and 218 fish at the beginning of the 6 mo holding period in low-dose and high-dose exposures, respectively

\begin{tabular}{|lrccc|}
\hline Treatment & $\begin{array}{c}\text { Mean } \\
\text { mortality }\end{array}$ & Range & $\begin{array}{c}\text { Mean \% } \\
\text { mortality }\end{array}$ & SD \\
\hline Low-dose (Nov 2000) & & & & \\
Filtered & 4.25 & $2-7$ & 4.13 & 2.16 \\
Unfiltered & 10.75 & $8-17$ & 10.44 & 4.07 \\
High-dose (Mar 2001) & & & & \\
Filtered & 8.25 & $3-15$ & 3.79 & 2.35 \\
Unfiltered & 144.25 & $142-147$ & 66.15 & 1.01 \\
\hline
\end{tabular}


period in order to maintain adequate flow of filtered water to the test fish. We suspect this process may have allowed a small amount of the unfiltered effluent to percolate vertically along the edges of the stock tank and pass through to the test fish.

Periodic removal of the top layer of sand to keep flow rates, hydraulic head loss and other filtration parameters within acceptable levels in sand filtration systems is common practice (Seelaus et al. 1986, Schuler et al. 1991). The time period between successive removals of the surface layer of sand is known as the 'filtration cycle'. While the $2 \mathrm{~d}$ filtration cycle in our high-dose exposure was not an undue hardship, it would be unacceptable in an operational application. Trapping of particulates in the surface sand can result in significant loss of head pressure and dramatic declines in filtration efficiency. Even in areas where the turbidity level and particulate loading in the water is quite low, filtration cycles are generally 30 to $60 \mathrm{~d}$ (Seelaus et al. 1986, Schuler et al. 1991). There are 2 common solutions to this problem: removal and replacement of the clogged sand layer or designing a system that enables the sand filter to be periodically back-flushed.

Other technologies have been developed and used to remove infective stages of Myxobolus cerebralis and other pathogens from water supplies in commercial aquaculture. These include ozone treatment (Williams et al. 1982, Horsch 1987), ultraviolet irradiation (Hoffman 1974, 1975, Hedrick et al. 2000) and chemical treatment of soils in ponds with calcium oxide, calcium cyanamide, or chlorine or calcium hypochlorite (Hoffman 1990). While these approaches may be effective in some cases, they can be cost-prohibitive or prone to failure if electrical power is interrupted. This certainly would be the case for ultraviolet irradiation. Periodic shutdown of ozone treatment systems can be problematic as well (Horsch 1987). Chemical treatments of soils or water may not be environmentally acceptable and can require periodic reapplication to maintain control of the parasite. For these reasons, passive sand filtration was our preferred method.

Based on the success of these tests, a slow sandfiltration system has been designed in collaboration with civil engineers and constructed at the outlet of the Myxobolus cerebralis -contaminated ponds on the Fryingpan River. The system is designed for flow rates up to $34001 \mathrm{~min}^{-1}$ on a sustained basis. The filter can be back-flushed to purge accumulated detritus in order to maintain head pressure and flow volume. Design criteria indicate that the filter should be capable of reducing $M$. cerebralis TAM density by $\geq 95 \%$. We hope that these efforts will lead to the development of techniques for constructing wetland 'biofilters' capable of removing TAMs from the effluent of spring-fed ponds and small man-made lakes enzootic for the $M$. cerebralis parasite

Acknowledgements. We wish to thank the many Colorado chapters of Trout Unlimited, and the Whirling Disease Foundation for substantial amounts of funding that in large part covered the costs of completing these studies. We are appreciative of the Colorado Division of Wildlife Aquatic Animal Health Laboratory staff for completion of the PTD analyses as well as L. Chittum, DVM, for the histological evaluations. In addition, the authors and the Colorado Division of Wildlife are deeply grateful to J. Gilchrist, L. Nichols, and the Nichols family and staff at the Cap K Ranch for their cooperation in allowing access to the ponds on the ranch so that these studies could be conducted.

\section{LITERATURE CITED}

Andree KB, MacConnell E, Hedrick RP (1998) A nested polymerase chain reaction for the detection of genomic DNA of Myxobolus cerebralis in rainbow trout Oncorhynchus mykiss. Dis Aquat Org 34:145-154

Arndt RE, Wagner EJ (in press) Filtering Myxobolus cerebralis triactinomyxons from contaminated water using rapid sand filtration. Aquacult Eng

Baldwin TJ, Vincent ER, Silflow RM, Stanek D (2000) Myxobolus cerebralis infection in rainbow trout (Oncorhynchus mykiss) and brown trout (Salmo trutta) exposed under natural conditions. J Vet Diagn Investig 12: 312-321

Bellamy WD, Silverman GP, Hendricks DW, Logsdon GS (1985) Removing Giardia cysts with slow sand filtration. J Am Water Works Assoc 77:52-60

Cleasby JL, Hilmoe DJ, Dimitrarcopoulos CJ (1984) Slow sand and direct in-line filtration of a surface water. $\mathrm{J}$ Am Water Works Assoc 76:44-55

El-Matbouli M, Hoffmann RW (1998) Light and electron microscopic studies on the chronological development of Myxobolus cerebralis to the actinosporean stage in Tubifex tubifex. Int J Parasitol 28:195-217

El-Matbouli M, Fischer MT, Hoffmann RW (1992) Present knowledge on the life cycle, taxonomy, pathology, and therapy of some Myxosporea ssp. important in freshwater fish. Annu Rev Fish Dis 367-402

Hazen A (1913) The filtration of public water supplies. John Wiley \& Sons, London

Hedrick RP, McDowell TS, Marty GD, Mukkatira K, Antonio DB, Andree KB, Bukhari Z, Clancy T (2000) Ultraviolet irradiation inactivates the waterborne infective stages of Myxobolus cerebralis: a treatment for hatchery water supplies. Dis Aquat Org 42:53-59

Hoffman GL (1974) Disinfection of contaminated water by ultraviolet irradiation, with emphasis on whirling disease (Myxosoma cerebralis) and its effect on fish. Trans Am Fish Soc 103:541-550

Hoffman GL (1975) Whirling disease (Myxosoma cerebralis) control with ultraviolet irradiation and effect on fish. J Wildl Dis 11:505-507

Hoffman GL (1990) Myxobolus cerebralis, a worldwide cause of salmonid whirling disease. J Aquat Anim Health 2:30-37

Horsch CM (1987) A case history of whirling disease in a drainage system: Battle Creek drainage of the upper Sacramento River basin, California, USA. J Fish Dis 10:453-460 
Lange KP, Bellamy WD, Hendricks DW, Logsdon GS (1986) Diatomaceous earth filtration of Giardia cysts and other substances. J Am Water Works Assoc 78:76-84

Lom J, McGeorge J, Feist SW, Morris D, Adams A (1997) Guidelines for the uniform characterisation of the actinosporean stages of parasites of the phylum Myxozoa. Dis Aquat Org 30:1-9

Markiw ME, Wolf K (1974) Myxosoma cerebralis: isolation and concentration from fish skeletal elements-sequential enzymatic digestions and purification by differential centrifugation. J Fish Res Board Can 31:15-20

Markiw ME, Wolf K (1983) Myxosoma cerebralis (Myxozoa: Myxosporea etiologic agent of salmonid whirling disease requires tubificid worm (Annelida: Oligochaeta) in its life cycle. J Protozool 30:561-564

Musial C, Arrowood M, Sterling C, Gerba C (1987) Detection of Cryptosporidium in water by using polypropylene cartridge filters. Appl Environ Microbiol 48:687-692

Nehring RB, Thompson KG (2001) Impact assessment of some physical and biological factors in the whirling disease epizootic among wild trout in Colorado. Colorado Division of Wildlife, Special Report No. 76, Fort Collins, CO

Nehring RB, Thompson KG, Taurman KA, Shuler DL (2002) Laboratory studies indicating that living brown trout Salmo trutta expel viable Myxobolus cerebralis myxospores. In: Bartholomew JL, Wilson JC (eds) Whirling disease: reviews and current topics. American Fisheries Society, Bethesda, MD, p125-134

Oram BF (1987) The removal of Giardia cysts and other contaminants using diatomaceous earth filtration with chemical additive MSc thesis, Pennsylvania State University,

Editorial responsibility: Carl Schreck,

Corvallis, Oregon, USA
College Park, PA

Piper RG, McElwain IB, Orme LE, McCraren JP, Fowler LG, Leonard JR (1982) Fish hatchery management. US Department of Interior Fish and Wildlife Service, Washington, DC

Schisler GJ, Bergersen EP, Walker PG, Epp JK (2001) Comparison of single-round polymerase chain reaction (PCR) and pepsin-trypsin digest (PTD) methods for detection of Myxobolus cerebralis. Dis Aquat Org 45:109-114

Schuler PF, Ghosh MM (1990) Diatomaceous earth filtration of cysts and other particulates using chemical additives. J Am Water Works Assoc 82:67-75

Schuler PF, Ghosh MM, Gopolan P (1991) Slow sand and diatomaceous earth filtration of cysts and other particulates. Water Res 25:995-1005

Seelaus TJ, Hendricks DW, Janonis BA (1986) Design and operation of a slow sand filter. J Am Water Works Assoc 78:35-41

Thompson KG, Nehring RB (2000) A simple technique used to filter and quantify the actinospore of Myxobolus cerebralis and determine its seasonal abundance in the Colorado River. J Aquat Anim Health 12:316-323

Thompson KG, Nehring RB, Bowden DC, Wygant T (1999) Field exposure of seven species or subspecies of salmonids to Myxobolus cerebralis in the Colorado River, Middle Park, Colorado. J Aquat Anim Health 11:312-329

Williams RC, Hughes SG, Rumsey GZ (1982) Use of ozone in water re-use system for salmonids. Prog Fish-Cult 44: 102-105

Wolf K, Markiw ME (1984) Biology contravenes taxonomy in the Myxozoa: new discoveries show alternation of invertebrate and vertebrate hosts. Science 225:1449-1452

Submitted: September 15, 2002; Accepted: July 1, 2003

Proofs received from author(s): September 29, 2003 